\title{
Effect of Local Microorganism Utilization to Increase Productivity of Javanese Turmeric (Curcuma xanthorriza Roxb.)
}

Authors

Affiliation
Lucky Lia Faiza ${ }^{1}$,Poppy F. Arifin ${ }^{1}$, Waras Nurcholis ${ }^{2}$, Taufik Ridwan ${ }^{2}$, Latifah K. Darusman ${ }^{2}$, Raphael Aswin Susilowidodo ${ }^{1}$, Rosalina Wisastra ${ }^{1}$

${ }^{1}$ SOHO Centre of Excellence in Herbal Research (SCEHR), SOHO Global Health, Indonesia

${ }^{2}$ Tropical Biopharmaca Research Center, Bogor Agricultural University, Indonesia

\section{Keyword}

Fruits LMO

O Javanese turmeric

O Local microorganism

$\rightarrow$ Secondary metabolite

? Snails LMO

Received 2 July 2018

Revised 6 August 2018

Accepted 24 August 2018

*Corresponding author Lucky Lia Faiza SOHO Global Health, Cihanjawar, Nagrak, Sukabumi 43356, Indonesia lucky.lia@sohoglobalhealth.co $m$

\section{ABSTRACT}

The quality of javanese turmeric as one of the most widely use herb in Indonesian traditional medicine, is often ignored and unoptimized. Therefore, research on Javanese turmeric cultivation become critical to be performed.One of crucial aspect is sufficiency of water and nutrients to increase rhizome productivity during vegetative period. Therefore, fertilization plays an important role in increasing soil macronutrients content and ultimately enhance Javanese turmeric's quality. The aim of this research is to determine the potential of addition local microorganism (LMO) solution as an organic fertilizer on rhizome production and bioactive content of Javanese Turmeric .

The research on LMO application for Javanese turmeric plantation was conducted at Soho Center of Excellence in Herbal Research (SCEHR). LMO was made by utilizing local waste of snail and fruits collected from around plantation area. Three different groups of treatment were applied, one group as a control and two groups were treated by additional LMO along vegetative period. The measured parameters were weight of rhizome, curcuminoid and xanthorrhizol levels. The results showed that LMO addition to the regular fertilization able to increase Javanese turmeric productivity and shorten both vegetative and generative period of time while maintain its quality. It can be concluded that LMO application is also good approach for both field, Javanese turmeric agriculture and natural medicine.

\section{INTRODUCTION}

Factors that affect the quality of traditional medicine include the quality of the ingredients utilized in the production of said medicine, as well as the quality of the dosage form. Therefore, the assurance and rising of quality of traditional herbal drugs go hand in hand with that of the ingredients. One herb that is often used in Indonesian traditional medicine is Javanese turmeric (Curcuma xanthorrhiza Roxb), in Indonesia it is common called as Temulawak. Javanese turmeric is known to possess many benefits as an antiinflammation (Jacob 2007), antioxidant (Kumar et al. 2007), anticancer 
(Thangapazham et al. 2008), antimicrobial (Goel 2008), hepatoprotective (Farombi 2007), and antihyperlipidemic (Arafa 2005), among others. These attributes are connected to the active marker compounds found in Javanese turmeric, curcuminoids and xanthorrhizol (Sidik and Sumiwi 2008). These secondary metabolic products are often used as indicators of the Javanese turmeric's quality, because the effect of active markers level on its potency is significant.

Javanese turmeric is a perennial plant that takes approximately 9-12 months to harvest. Optimal growth conditions are 100-600 $\mathrm{m}$ above sea level with soil that has good drainage, medium solum, a texture ranging from clay to sandy loam and a loose consistency. The relatively long harvest time makes the cultivation of Javanese turmeric unattractive notion to many, especially when compounded with the fact that the quality of the resulting plant is rarely up to expectations. Low concentrations of curcuminoids and xanthorrhizol often become a stumbling block in upkeeping Javanese turmeric quality, as well as a crucial question in relation to optimal harvesting methods that yield the best results (Rahardjo 2010).

Javanese turmeric takes a long time to harvest because it has two periods of growth, a vegetative phase and a generative phase. The former is growth of the shoot, rhizomes, and other primary metabolites, and hence requires nutritional support; a lot of effort goes into enriching soil with nutrition by fertilization. Fertilization, such as composting yields a faster vegetative growth in terms of stem height and diameter, as well as the length, width, and number of leaves, compared to most other methods (Rivai, 2017). Another method would be to use microorganisms to increase macronutrients in the soil. Some types of microorganisms can increase the concentration of phosphorus in soil, which is the most essential macronutrient for plant growth after nitrogen (Gyaneshwar et al. 2002).

On the other hand, the generative phase is when the plant is out of the vegetative phase and begin to focus on secondary metabolic growth, and this is the period in which curcuminoids and xanthorrhizol are developed. Many factors, including physiological variables such as organ growth, pollination, or chemical or mechanical damage to the plant affect this development. Other possible factors are pests and diseases, temperature, climate, and contamination (Figueiredo et al. 2008).

The use of local microorganisms (LMO) has many applications in the vegetative phase of growth. LMO is a fluid made from several natural sources, containing various nutrient elements and microbes that can break down organic material (Suhastyo et al. 2013). Thus LMO can be expected to mend soil conditions and optimize vegetative growth for productivity of the plant. Therefore, it can also maximize formation of secondary metabolites to increase curcuminoid and xanthorrhizol concentrations. It would be even better if the addition of LMO can shorten the long harvesting time by increasing the rate of secondary metabolite formation despite still being in the vegetative phase, making the cultivation of Javanese turmeric much more feasible.

This method is expected to impart benefits on farming as a complement to fertilization. The use of LMO is acceptable within the principles of organic farming as it only involves organic material and does not leave chemical residue in the soil.

\section{METHODS}

The study was conducted between November 2014 and August 2015 at the Soho Center of Excellence in Herbal Research (SCEHR) in Sukabumi, Indonesia, 600 $\mathrm{m}$ above sea level. The Javanese turmeric seed used was of the Cursina 2 variety and planted in $70 \times 50 \mathrm{~cm}$ square holes, approximately 50-100 $\mathrm{g}$ of seeds per hole. Manure was used as an initial nutrition provider with a dose of $1 \mathrm{~kg} / \mathrm{hole}$.

Two LMO types were utilized for this study: LMO made from snails (SLMO) and LMO made from rotten fruits (FLMO). They were formulated by chopping up the material ( $1 \mathrm{~kg}$ of snails or fruit) and mixing them with 5 liters rice washing water/fish water that had been added with $250 \mathrm{~g}$ molasses/sugar. Each mixture was stirred 2-3 times every day and was prepared for 17-20 days. The resulted mixture are then called a LMO stock solutions.

LMO was applied during the Javanese turmeric vegetative phase by spraying a diluted solution (LMO stock solution in water with $1: 10 \mathrm{v} / \mathrm{v}$ ratio). Three groups of treatment were assigned, the plants given only manure as the control, the plants given manure plus Fruit Local Micro Organism (FLMO) during the vegetative phase, and the plants given manure plus 
Snail Local Micro Organism (SLMO) during the vegetative phase.

The experiment was carried out with simploThe aim is to determine whether the addition of LMO has an effect as a complementary nutrient for the growth of Javanese turmeric and as stimulant for Javanese turmeric bioactive metabolite formation.

Observations were made on the 7th, 8th, and 9th months after planting, measuring the productivity (weight) of rhizomes and concentrations of bioactive chemicals in the rhizomes, i.e. xanthorrhizol and curcuminoids. This is to determine the optimal planting period of Javanese turmeric with the additions of nutrients like LMO during planting period, in order to attain a shorter planting period. Analysis of curcuminoid and xanthorrhizol concentrations was done with high performance liquid chromatography (HPLC).

Assay of curcuminoid was determined using C18, $250 \times 4.6 \mathrm{~mm}, 5 \mu \mathrm{m}$ column. Mobile phase was made by acetronitrile: $\mathrm{H}_{3} \mathrm{PO}_{4} \quad 0.1 \%$ (60:40). Target compound was detected using $425 \mathrm{~nm}$ wavelength at retention time \pm 7.2 minutes for Bis-demetoxycurcumin, retention time \pm 7.8 minutes for demetoxycurcumin and retention time \pm 8.4 minutes for curcumin.

Assay of xanthorrhizol was determined by injecting the sample which dissolved in ethanol to HPLC system using C18, $150 \times 4.6 \mathrm{~mm}, 5 \mu \mathrm{m}$ column. Mobile phase was made by methanol:water (80:20) and $280 \mathrm{~nm}$ wavelength was used as detector to show target compound at retention time \pm 9.6 minutes.

\section{RESULTS AND DISCUSSION}

Adding local microorganisms is a means for increasing nutrient content during the growth of the Javanese turmeric plant. The long planting period and the addition of LMO during the vegetative phase showed an effect on productivity of rhizomes. The single addition of manure during the initial planting phase yielded least productivity compared to the groups with LMO, as seen in Fig. 1. Javanese turmeric given manure + LMO has larger rhizomes and have higher productivity at 7 months after planting (m.a.p.) than the control Javanese turmeric at 9 m.a.p.

The materials used in LMO also have different effects. The two types of LMO, fruit and snail, have different productivity patterns from month to month. FLMO generated a higher increase in productivity than SLMO, giving wet rhizomes as large as $1,220 \mathrm{~g} / \mathrm{plant}$ and dry rhizomes as large as $230 \mathrm{~g} /$ plant at 9 m.a.p. But SLMO gave better results than fruit at 7 m.a.p. and 8 m.a.p.

Rhizome productivity is a target of every Javanese turmeric cultivation as it is the main part of the plant to be utilized, especially since it has long planting period which means farmers can only grow it once a year. Generally, rhizome productivity is influenced by growth quality during the vegetative phase; soil conditions and nutrients are significant in ensuring maximal growth and formation of primary metabolites that has a direct relationship with rhizome productivity. Macronutrients required for rhizome growth are nitrogen, potassium, calcium, magnesium, phosphorus, and sulphur, while micronutrients required for plant growth are iron, zinc, manganese, copper, and chlorine (Grusak, 2001). Sufficiency of these nutrients is important to the resulting quality of rhizomes, which in turn is often based on the concentration of marker compounds in it because of the correlation between concentration and potency.

Fertilization is mandatory to increase soil nutrient, but that alone does not guarantee quality yield, particularly with regards to active compound concentration in rhizomes. Even though LMO was only applied during the vegetative phase, it has an effect not only on Javanese turmeric productivity but also on the concentrations of curcuminoids and xanthorrhizol in rhizomes, as recorded in Table 1.

In table 1 shown that curcuminoid concentration is increase with plant age from all treatment group. LMO also gives a positive influence on curcuminoid concentration, although manure + SLMO yielded better than manure + FLMO. The highest concentration of curcuminoids was $1.93 \%$ - attained with manure + SLMO fertilizer at 9 m.a.p. - albeit not being too far from the control results, $1.92 \%$.

Unlike curcuminoids,xanthorrhizol in the experimental groups displayed a distinct pattern of growth from the control group. With manure only, xanthorrhizol concentration increased with age, but with LMO, it peaked at 7 m.a.p. and then declined with age. The highest concentration of xanthorrhizol was $4.17 \%$, in manure + SLMO at 7 m.a.p.

The addition of LMO on top of regular fertilizer is proven to be crucial and makes a significant difference for both productivity and its bioactive concentration. From a productivity standpoint, LMO can increase rhizome weight; at 9 m.a.p. the control group has 


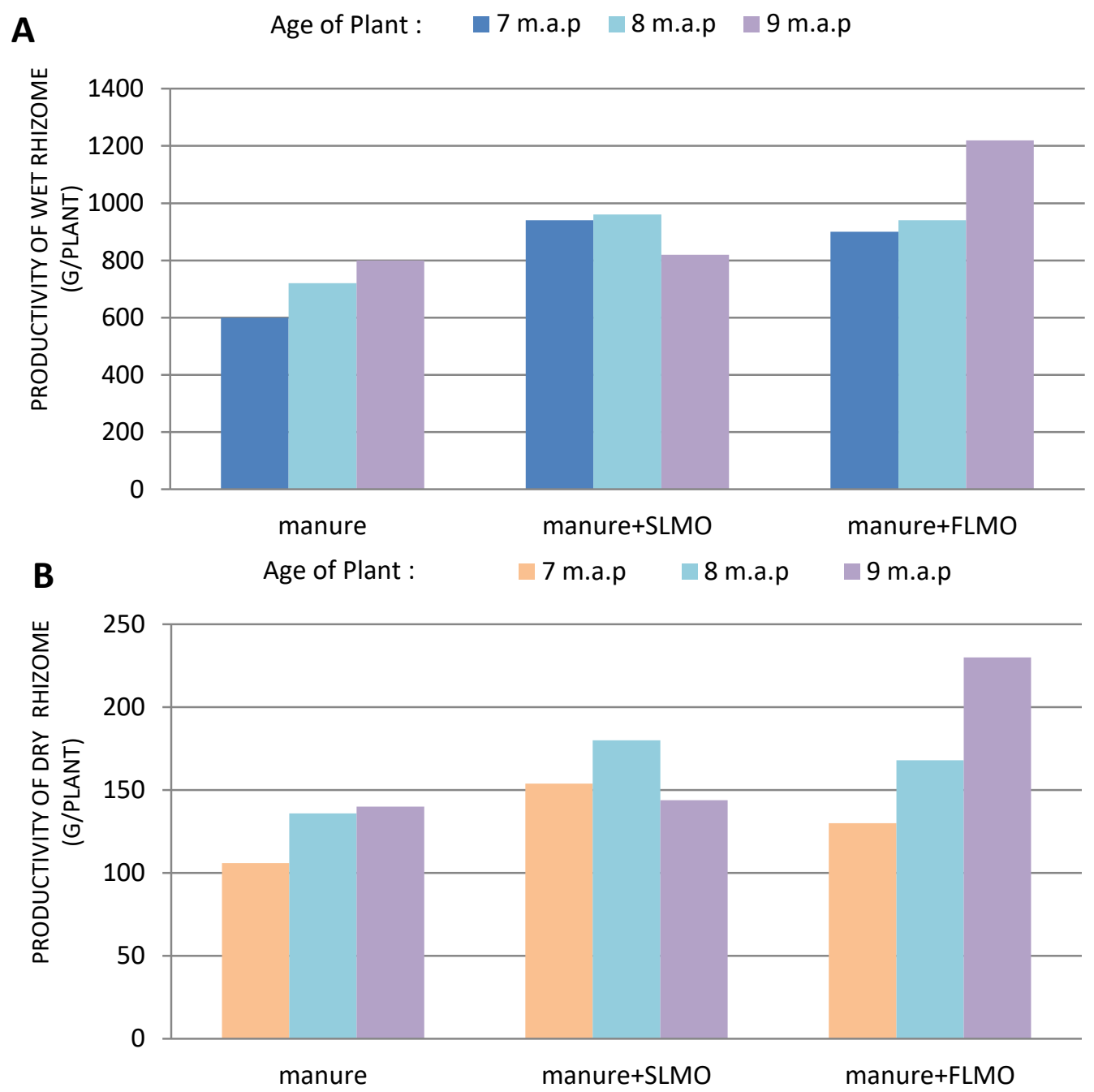

Figure 1. Productivity of wet (A) and dry (B) javanese turmeric rhizomes according to cultivation methods of age.

smaller rhizomes than the treatment group of manure + SLMO and manure + FLMO groups at 7 m.a.p. This result indicate that adding $\mathrm{LMO}$ to the plant during Javanese turmeric vegetative period worthy of consideration. Application of LMO can make plantation period shorter while keeping its productivity at an optimal level.

Aside from rhizome productivity, bioactive compounds in those rhizomes is a parameter for considering and determining simplicial quality. The formation of these compounds generally occurs in the generative phase of growth when the Javanese turmeric has formed its primary metabolites. The formation of secondary metabolites is influenced by age, condition, and environment in which the plant is grown. These factors will affect biochemical mechanisms in said formation. From medical point of view, curcuminoid and xanthorrizol concentration in Javanese turmeric is even more crucial than the rhizome weight. Higher bioactive content enable Javanese turmeric to broaden its health benefit as natural medicine. It is well know that curcuminoids and xanthorrhizol have antiinflammation (Devaraj et al. 2010), antioxidant (Aftab and Vieira, 2010), and antimicrobial towards $H$. pylori (De et al. 2009). Xanthorrhizol can also be an oral antimicrobial (Hwang et al. 2000), anti-Candida (Rukayadi et al. 2006), and in combination with curcumin can halt the growth of MDA-MB- 231 cells that induce breast cancer (Cheah et al. 2009). These wide benefits can only be reached with a high quality of Javanese turmeric that has an adequate amount of curcuminoid and xanthorrizol up 
Table 1. The effect of manure and LMO and plant age on concentrations of curcuminoid and xanthorrhizol in rhizomes.

\begin{tabular}{ccccc}
\hline \multirow{2}{*}{ Age of plant } & Bioactive & \multicolumn{3}{c}{ Fertilizer } \\
\cline { 3 - 4 } & & Manure & $\begin{array}{c}\text { Manure + Snail } \\
\text { LMO }\end{array}$ & $\begin{array}{c}\text { Manure + Fruit } \\
\text { LMO }\end{array}$ \\
\hline 7 & Curcuminoid & $0.96 \%$ & $1.55 \%$ & $1.06 \%$ \\
& Xanthorrhizol & $3.26 \%$ & $4.17 \%$ & $3.70 \%$ \\
8 & Curcuminoid & $1.21 \%$ & $1.75 \%$ & $1.11 \%$ \\
& Xanthorrhizol & $3.32 \%$ & $3.65 \%$ & $3.03 \%$ \\
& Curcuminoid & $1.92 \%$ & $1.93 \%$ & $1.44 \%$ \\
& Xanthorrhizol & $3.45 \%$ & $3.51 \%$ & $2.37 \%$ \\
\hline
\end{tabular}

to certain level of standard. The cultivation become one of its most important factor to obtain that.

The addition of $L M O$ resulted in an increase in curcuminoid concentration that rises with age. Interestingly, concentration at 7 m.a.p. in LMO-treated plants is significantly different than in those with manure only. This warrants further research in the use of LMO for the cultivation of Javanese turmeric. Xanthorrhizol concentration showed a distinct pattern from that of curcuminoids with a decrease with age, the highest value being observed at 7 m.a.p., in LMOtreated plants. These results was in line with our hypothesis that LMO not only able to enhance Javanese turmeric vegetative growth but could be also able to maximize the formation of secondary metabolites curcuminoid and xanthorrhizol concentrations.

The materials used in creating the LMO solution also has an effect on the results. SLMO generally gives better results than FLMO. This can be a basis for further study with regards to the ingredients that go into making LMO solutions. Macro- and micronutrient contents is the primary factor in influencing yield. According to Suhastyo et al. (2013), nutrients found in SLMO are, among others, $\mathrm{Mg}, \mathrm{Cu}, \mathrm{Zn}, \mathrm{Mn}$, and Fe. Calcium is the macronutrient tied with plant cell activity in stimulus response and signal transduction. Phosphorus is needed for increasing plant growth in dehydrated conditions when Javanese turmeric is growing in dry condition. These elements in LMO will have a positive impact on Javanese turmeric growth in both vegetative and generative phases.

\section{CONCLUSION}

The higher the curcuminoid and xanthorrhizol content indicate the higher the quality. LMO addition to the regular fertilization able to increase Javanese turmeric productivity and shortened both vegetative and generative period of time while maintaining its quality. Taking all these into account suggest that LMO application is a good approach for both field, Javanese turmeric agriculture and natural medicine. However, although LMO usage can be one way to increase concentrations, further study is needed in relation to dosage or organic materials that can be used in making solutions.

\section{REFERENCES}

Aftab N, Vieira A. 2010. Antioxidant Activities of Curcuminoid with other Phytochemicals. Phytotherapy Research. 24: 500-502.

Arafa H. 2005. Curcumin attenuates diet-induced hypercholesterolemia in rats. Medical Science Monitor. 11(7): 228-234.

Cheah, YH, Nordin, FJ, Sarip R, Tee TT, Azimahtol HL, Sirat HM, Rashid BAA, Abdullah NR, Ismail Z. 2009. Combined xanthorrhizol-curcumin exhibits synergistic growth inhibitory activity via apoptosis induction in human breast cancer cells MDA-MB231. Cancar Cell International. 9(1).

De R, Parag K, Snehasikta S, Ramamurthy T, Abhijit C, Nair GB, Asish M. 2009. Antimicrobial Activity of Curcumin againstHelicobacter pylorilsolates from India and during Infections in Mice. Antimicrobial Agents and Chemotherapy. 53(4): 1592-1597.

Devaraj S, Esfahani A S, Ismail S, Ramanathan S, Yam MF. 2010. Evaluation of the Antinociceptive Activity and Acute Oral Toxicity of Standardized Ethanolic Extract of the Rhizome of Curcuma xanthorrhiza Roxb. Molecules. 15(4): 2925-2934.

Devy L. 2009. Analysis of variance and genetic stability of temulawak (Curcuma xanthorrhiza Roxb) in

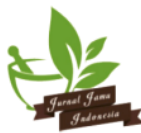


Indonesia. [tesis]. Bogor (ID): Institut Pertanian Bogor.

Farombi E, Shrotriya S, Na H, Kim D, Surh Y. 2007. Curcumin attenuates dimethylnitrosamine-induced liver injury in rats through Nrf2-mediated induction of heme oxygenase- 1 . Food and Chemical Toxicology. 46(4): 1279-87.

Figueiredo AC, Barroso JG, Pedro LG, Scheffer JJ. 2008. Factors affecting secondary metabolite production in plants: volatile components and essential oils. Flavour and Fragrance Journal. 213-226.

Goel A, Kunnumakkara A, Aggarwal B. 2008. Curcumin as "Curecumin": from kitchen to clinic. Biochemical Pharmacolog. 787-809.

Grusak MA. 2001. Plant Macro- and Micronutrient Minerals. Encyclopedia of Life Sciences.

Gyaneshwar P, Kumar GN, Parekh L, Poole PS. 2002. Role of soil microorganisms in improving $P$ nutrition of plants. Plant and Soil. 15;75(4): 83-93.

Herlina. 2011. Kajian variasi jarak dan waktu tanam jagung manis dalam sistem tumpangsari jagung manis (Zea mays). Padang [ID]: Universitas Andalas.

Hwang JK, Shim JS, Pyun Y. 2000. Antibacterial activity of xanthorrhizol from Curcuma xanthorrhiza against oral pathogens. Fitoterapia, 245(1): 321323.

Indriati TR. 2009. Pengaruh Dosis Pupuk Organik dan Populasi Tanaman terhadap Pertumbuhan serta Hasil Tumpangsari Kedelai (Glycine max L.) dan Jagung (Zea mays L.). Program Pascasarjana. Solo (ID): Universitas Sebelas Maret.

Islam, F., Karim, M. R., Shahjahan, M., Hoque, M. O., Alam, M. R., \& Hossain, M. A. (2002). Study on the Effect of Plant Spacing on the Production of Turmeric at Farmer's Field. Asian Journal of Plant Sciences: 616-617.

Hwang JK, Shim JS, Pyun YR 2000. Antibacterial activity of xanthorrhizol from Curcuma xanthorrhiza against oral pathogens. Fitoterapia. 71(321-323).

Jacob A, Wu R, Zhou M, Wang P. 2007. Mechanism of the Anti-inflammatory Effect of Curcumin: PPARgamma Activation. PPAR Res. 89369.

Kumar P, Padi S, Naidu P, Kumar A. 2007. Possible neuroprotective mechanisms of curcumin in attenuating 3-nitropropionic acid-induced neurotoxicity. Methods and findings in experimental and clinical pharmacology. 29(1): 1925.
Nurcholis W, Ambarsari L, Purwakusumah ED. 2016. Curcumin analysis and cytotoxic activities of some curcuma xanthorrhiza roxb. Accessions. International Journal of PharmTech Research. 9(7):175-180

Rahardjo M. 2010. Penerapan SOP budidaya untuk mendukung temulawak sebagaibahan baku obat potensial. Perspektif, 9(2): 78-93.

Rina D. 2015. Manfaat unsur N,P, dan K bagi tanaman. Badan Litbang Pertanian Kalimantan Timur.

Rivai,RR. Wardani FF. 2017. Aplikasi pemanfaatan pupuk kompos pada fase vegetatif tanaman obat Alpinia malaccensi. Prosiding Seminar Nasional Masyarakat Biodiversitas Indonesia. 154-156.

Ronita De PK. 2009. Antimicrobial Activity of Curcumin against Helicobacter pylori Isolates from India and during Infections in Mice. Antimicrobial Agents Chemotherapy. 53(4): 1592-1597.

Rukayadi Y, Yong D, Hwang JK. 2006. In Vitro ANticandidal activity of xanthorrhizol isolated from Curcuma xanthorrhiza Roxb. Journal of Antimicrobial Chemotherapy. 57,6(1):1231-1234.

Sidik, Sumiwi SA. 2009. Temulawak (Curcuma xanthorrhiza Roxb) Botany, Etnobotany Chemistry, Pharmacology and There Benefit. Proceedings of The First International Symposium on Temulawak Bogor - Indonesia: Biopharmaca Research Center Bogor Agricultural University.

Song YN, Zhang FS, Marschner P, Fan FL, Gao HM, Bao $X G$, Sun JH, Li L. 2007. Effect of intercropping on crop yield and chemical and microbiological properties in rizhosfer of wheat (Triticum aestivum L.), maize (Zea mays L.), and faba bean (Vicia faba L.). Biology and Fertility of Soils. 43(5): 565-574.

Suhastyo AA, Anas I, Santosa DA, Lestari Y. 2013. Studi Mikrobiologi dan Sifat KImia Mikroorganisme Lokal (MOL) yang DIgunakan pada Budidaya Padi Metode SRI (System of RIce Intensification). Sainteks. 2.

Sutha Devaraj AS. 2010. Evaluation of the Antinociceptive Activity and Acute Oral Toxicity of Standardized Ethnaolic Extract of the Rhizome of Curcuma xanthorrhiza Roxb. Molecules. 15(4): 2925-2934.

Thangapazham R, Puri A, Tele S, Blumenthal R, Maheshwari R. 2008. Evaluation of a nanotechnology-based carrier for delivery of curcumin in prostate cancer cells. International Journal of Oncology. 32(5): 1119-23. 